\title{
Religious Freedom as a Human Right: An International Overview Focusing on Brazil
}

\author{
Cláudio Antônio Klaus Júnior \\ Law Course \\ Alto Vale do Rio do Peixe University, Brazil \\ Rua Victor Baptista Adami, no 800 \\ Centro, Caçador, Santa Catarina, Brazil \\ ZIPCODE 89500-199 \\ Joel Cezar Bonin \\ Postgraduate Program in Basic Education \\ Levi Hülse \\ Adelcio Machado dos Santos \\ Joel Haroldo Baade \\ Postgraduate Programs in Development and Society and Education
}

\begin{abstract}
The present work aims to present the concept of religious freedom as a human right along with its history and law around the world pointing towards practices in Brazil. It presents an analysis of the Brazilian constitution and how it relates to international treaties. Presents cases of intolerance and conflict resolution in the country.Brazil can become a major global force for religious freedom. The country's governmental tendencies are to be in favor of religious freedom and committed to protecting the free exercise of religion, both in private and in public. But, as clearly shown in the data, Brazil certainly has a history of religious changes in peaceful navigation that is worth noting.
\end{abstract}

Keywords: religious freedom, human rights, tolerance, diversity, juridical relationship,civil society.

\section{The Concept of Religious Freedom}

"First, do no harm." That maxim from Hippocrates ${ }^{1}$ has universal appeal. Yet today, it is being used as the title of a bill that would do great harm to one of our most cherished natural rights: Religious freedom ${ }^{2}$. The world view people are raised to have is something that sticks to our very core when we don't work towards disrupting the status quo and the strength of such a mindset. The world as see it, might not be exactly what it is, if we take an anthropological view of things, for example, we can see that there is a relativization of a culture where what is done elsewhere seems strange and not right. Discussion of the human right to religious freedom calls for further inquiry into the foundations of the juridical relationship among human beings in civil society. The concept of a juridical relationship properly includes the notion of a correspondence between rights and duties.

Some of these inconvenient truths and perspectives make world relevant questions to be postponed and even disrupt development. In a world where indifference seems to be the big word of the century it is hard to fight for sustainable development but those who do, have great chances of leaving a great legacy. While some choose to be present but also absent with their handheld devices some choose to make the difference they want to see in the world. Growing up in the street over the local cemetery made me want to be known in the day I died - the thought of being forgotten really frightened me. One of the subjects that seems to cause people to get uncomfortable is religious freedom.

While scientists, scholars and religious leaders seem to be realizing that the fighting for a "right" point of view doesn't add up to either side the freedom for exercising religion also is being threatened often. Religious freedom is essential to achieving social justice. In fact, the two causes are inseparable. Social justice promotes the idea that equal opportunities are essential to a just society, while religious freedom is the guarantee that each individual has the right to practice their

\footnotetext{
${ }^{1}$ ASCO POST. Relevance of the hippocratic oath in the 21st century [online]. Available: https://www.ascopost.com/issues/october-15-2014/relevance-of-the-hippocratic-oath-in-the-21st-century.aspx (June 4, 2019)

${ }^{2}$ JIPPING, Thomas. Diluting the substance of religious freedom [online]. Available: https://www.heritage.org/religiousliberty/commentary/diluting-the-substance-religious-freedom (June 4, 2019)
} 
faith and live their life in accordance with its values. Both ideas are congruent with the principal of equity for all people.

When Thomas Jefferson wrote the Virginia statute of religious freedom ${ }^{3}$, he attempted to address this compromise. He noted that the laws that benefit the group are the same that benefit the individual. That freedom for the individual is achieved when all people are free of imposition, and their thoughts exist as their own without infringement from the ideas of others. That diversity of thought and opinion is what makes this country successful and that our political system has a responsibility to foster this diversity.

Misinformation can be a great source of prejudice and affect the decision making both in government, justice and in day to day actions. While many advocates for a world where people are not influenced by feelings we can not rationalize the fact that we, as emotional beings, even trying to be as unaffected by outside perspectives as possible, still make decisions that will benefit us and our circles, both because of cooperation and social identity that can even lead to serious problems like corruption.

Throughout history, to this day, much of the conflict between peoples and nations has in its origin differences of creed that have fostered feelings of segregation and hostility against individuals or groups whose beliefs differ from the prevailing local practice. ${ }^{4}$

\section{Religious Freedom Throughout The World}

In the world, Religious freedom plays an important role, this important right was key to the foundation for countries like the United States of America. In an international overview a historical date was the one of the Universal Declaration of Human Rights which mentions in the Article 18: "Everyone has the right to freedom of thought, conscience and religion; this right includes freedom to change his religion or belief, and freedom, either alone or in community with others and in public or private, to manifest his religion or belief in teaching, practice, worship and observance."

The term "religious freedom" encompasses a number of distinct but related ideas. At the core is freedom of belief - in a god, gods or a higher realm or being. Many religions make absolute (and often mutually exclusive) claims to truth, most of which cannot be proven. Religions rely, instead, on acts of faith. Next comes freedom of worship - the freedom to perform, unhindered, the rituals associated with one's faith. Then there is the freedom to act in good conscience - to give effect to one's religious beliefs in the course of one's daily life and, as a corollary, not to be forced to act in a manner that would violate one's sacred obligations. Finally, there is the freedom to proselytise - to teach the tenets of one's religion to the faithful and to those who might be persuaded. ${ }^{6}$

Religious freedom has been linked to the UN Sustainable Development Goals, specially goal number $16^{7}$. A global study challenges myth of religious violence. The research found no general causal relationship between religion and conflict when looking at all of the current conflicts in the world. The study, conducted by the Institute for Economics and Peace (IEP) ${ }^{8}$ in conjunction with the Religious Freedom \& Business Foundation, aims to get beyond ideology to provide a more comprehensive understanding of how religion interacts with peace ${ }^{9}$.

Quantitative analysis has revealed that many of the commonly made statements surrounding the relationship between peace and religion are not supported by the analysis contained in this study. Countries with greater religious freedoms are generally more peaceful, whereas countries with less religious freedom are generally less peaceful. The most influential factor affecting religious freedom is the government type. Full democracies are the most peaceful and have the greatest level of religious freedom, regardless of the type of religious belief or various religious characteristics.

\footnotetext{
${ }^{3}$ VIRGINIA MUSEUM OF HISTORY AND CULTURE. ThomazJefferson [online]. Available: https://www.virginiahistory.org/collections-and-resources/virginia-history-explorer/thomas-jefferson (June 4, 2019)

${ }^{4}$ HARRY S. TRUMAN PRESIDENTIAL LIBRARY \& MUSEUM. To secure these rights [online]. Available: https://www.trumanlibrary.org/civilrights/srights4.htm (June 4, 2019)

${ }^{5}$ UNITED NATIONS. Universal declaration of human rights [online]. Available: https://www.un.org/en/universal-declaration-humanrights(June 4, 2019)

${ }^{6}$ ABC - AUSTRALIAN BROADCASTING CORPORATION. Human rights and the limits of religious freedom [online]. Available: https://www.abc.net.au/religion/human-rights-and-the-limits-of-religious-freedom/10286070(May 30, 2019)

${ }^{7}$ UN SUSTAINABLE DEVELOPMENT GOALS. Goal 16: promote just, peaceful and inclusive societies [online]. Available: https://www.un.org/sustainabledevelopment/peace-justice(June 3, 2019)

${ }^{8}$ RELIGIOUS FREEDOM \& BUSINESS FOUNDATION. Religious freedom linked to peace, finds new global study [online]. Available: https://religiousfreedomandbusiness.org/2/post/2014/10/religious-freedom-linked-to-peace-finds-new-global-study.html(June 3, 2019)

${ }^{9}$ RELIGIOUS FREEDOM \& BUSINESS FOUNDATION. Religious freedom \& sustainable development [online]. Available: https://religiousfreedomandbusiness.org/religious-freedom-sustainable-development(June 3, 2019)
} 


\section{The UN Academic Impact}

Portal features a researched promoted in the Mofid University (Iran) through its Centre for Human Rights Studies, the research is entitled Freedom of Religion in Quran and Traditions, Limits and Challenges ${ }^{10}$, aimed to answer these questions: Is it allowable in Islam to use coercive interference in human's thoughts?; What are the conceptions and examples of freedom of religion ${ }^{11}$ ?; and, What are the reasons for religious freedom from the perspective of the Quran and Sunnah?. The project is undergoing and it will be will be finished by the end of 2020 .

We have several countries that can give us examples in their way to treat such subjects. Canada's multi-cultural and multi-faith experience, for example, is reflective of Canadian efforts to champion inclusive and accountable governance, pluralism, and respect for diversity in all spheres of society ${ }^{12}$. Efforts to advance freedom of religion or belief internationally focus primarily on:

1. advocating on behalf of persecuted religious and belief communities under threat;

2. opposing religious hatred, discrimination and xenophobia; and

3. supporting dialogue among different religious groups where religious issues are principal factors of tension between communities

Recognizing the universal, indivisible, interdependent and interrelated nature of human rights, Global Affairs Canada continuously looks to broaden its approach to advancing freedom of religion or belief and engage with non-traditional partners. ${ }^{13}$ For example, freedom of religion or belief is often referred to as a "gateway" to other freedoms, including freedom of expression, and freedom of peaceful assembly and association, then freedom of religion or belief in its true meaning must be seen as empowering women to decide for themselves what they believe and how they wish to live.

Canada has made the promotion of pluralism and inclusion, and the recognition of and respect for diversity a priority, both at home and abroad, and works with partners to enhance the international promotion and protection of freedom of religion or belief. This country has been showing a good example of how to deal with these important right.

Other important treaties and historical documents are the 1966 International Covenant on Civil and Political Rights, the 1981 Declaration on the Elimination of All Forms of Intolerance and of Discrimination Based on Religion or Belief, In 1986 when the Establishment of the Special Rapporteur to identify existing and emerging obstacles to the enjoyment of the right to freedom of religion or belief took place and finally 1993 when the Human Rights Committee's General Comment Number 22 on Article 18 of the Civil and Political Covenant. ${ }^{14}$ In 2018 Margot Wallström, the Minister for Foreign Affairs of Sweden published the following statement: "Freedom of religion or belief is a universal human right. But despite this, people are persecuted, displaced and murdered because of their religion. Religious sites are destroyed and buildings set ablaze." ${ }^{\prime 15}$ In southern Brazil, we have experienced some cycles of migrations from 2013 to 2015 from Haiti $^{16}$ and now from 2017 on from Venezuela ${ }^{17}$ due to the civil and political crisis in those countries.

These cycles of migration have caused some disruptions in the thought process of several inhabitants, several people had really bad thoughts about those who are coming and were even worried about their background and how they would act in our society. Even though many challenges were raised due to the cultural differences also several things

\footnotetext{
${ }^{10}$ ACADEMIC IMPACT. \#sdgsinacademia: goal 16 [online]. Available: https://academicimpact.un.org/content/sdgsinacademia-goal-16(June 3, 2019)

${ }^{11}$ AISBERG - UNIVERSITY OF BERGAMO INSTITUTIONAL REPOSITORY. Rights of religious minorities and the principle of freedom of religion and belief: a human rights assessment and the case study of the Islamic Republic of Iran [online]. Available: https://aisberg.unibg.it/retrieve/handle/10446/28976/12214/tesi\%20completa\%20.pdf(June 3, 2019)

${ }^{12}$ GOVERNMENT OF CANADA. Freedom of religion or belief [online]. Available: https://international.gc.ca/worldmonde/issues_development-enjeux_developpement/human_rights-droits_homme/freedom_religion-liberte_religion.aspx?lang=eng(June 4, 2019)

${ }^{13}$ GOVERNMENT OF CANADA. Freedom of religion or belief [online]. Available: https://international.gc.ca/worldmonde/issues_development-enjeux_developpement/human_rights-droits_homme/freedom_religion-liberte_religion.aspx?lang=eng(June 4, 2019)

${ }^{14}$ OHCHR - UNITED NATIONS HUMAN RIGHTS. Report of the united nations special rapporteur on freedom of religion or belief to the general assembly [online]. Available:

https://www.ohchr.org/en/issues/freedomreligion/pages/reportsrtothegeneralassembly.aspx(May 30, 2019)

${ }^{15}$ GOVERNMENT OFFICES OF SWEDEN.Religious freedom is a fundamental human right [online]. Available:

https://www.government.se/opinion-pieces/2018/07/religious-freedom-is-a-fundamental-human-right(August 30, 2019)

${ }^{16}$ Audebert, Cedric. (2017). The recent geodynamics of Haitian migration in the Americas: refugees or economic migrants?.RevistaBrasileira de Estudos de População, 34(1), 55-71. https://dx.doi.org/10.20947/s0102-3098a0007(May 30, 2019)

${ }^{17}$ THE GUARDIAN. 'The strain is too much': venezuelan exodus has Brazil at breaking point [online]. Available: https://www.theguardian.com/global-development/2018/dec/24/venezuelan-exodus-brazil-at-breaking-point(May 30, 2019) 
arose to show that people and are worthy of rights just for the fact of being human. Such an inconvenient thing for people to have to deal with but still brought strength and even a mild mind shift.

Religious freedom seems to be a growing concern in several communities in different countries. Having had the chance to see the awareness of this fact being brought to my attention while living in Arizona and also when moving to southern Brazil. Different leaders gave talks and helped the inhabitants to understand the needs for such a right along with how people could protect themselves too. Still, there is a great gap around the topic and how religion and science don't seem to be getting along.

Religious freedom is more than just the freedom to believe what you want. It's also the freedom to talk about and act on your core beliefs without interference from government or others, except when necessary to protect health and safety. It also allows people with similar beliefs to form religious organizations that govern their own affairs ${ }^{18}$.

In Brazil, for example, we have important decisions to be made that needed the support of a faith-based community and these subjects cannot be ruled due to such difficult communication between the different political parties. ${ }^{19}$ Such misunderstandings also don't allow the political parties to support religious freedom and other important matters.

Religious freedom safeguards the right of all people to hold their own religious beliefs and express them openly without fear of persecution or being denied equal rights of citizenship. ${ }^{20}$ It ensures that people can freely choose or change their religion, teach their faith to their children, receive and disseminate religious information, gather with others to worship, and participate in the ceremonies and practices of their faith. It protects individuals from religious discrimination in employment, housing and other basic services, and prevents people from being denied the right to have a business, occupation, or professional license based on their religion.

That vision seems to be highly influential when we seek to defend our faith when we are debating a political or social concern. As mentioned before, the Article 18 of the International Covenant on Civil and Political Rights states that:

1. Everyone shall have the right to freedom of thought, conscience and religion. This right shall include freedom to have or to adopt a religion or belief of his choice, and freedom, either individually or in community with others and in public or private, to manifest his religion or belief in worship, observance, practice and teaching.

2. No one shall be subject to coercion which would impair his freedom to have or to adopt a religion or belief of his choice.

3. Freedom to manifest one's religion or beliefs may be subject only to such limitations as are prescribed by law and are necessary to protect public safety, order, health, or morals or the fundamental rights and freedoms of others.

4. The States Parties to the present Covenant undertake to have respect for the liberty of parents and, when applicable, legal guardians to ensure the religious and moral education of their children in conformity with their own convictions. ${ }^{21}$

Remarkably even after having such clear important information being widespread, in 2013, roughly 5.5 billion people 77 percent of the world's population -lived in countries with high or very high restrictions on religious liberty, up from 68 percent just six years earlier.

It is important to notice that breaking paradigms and disrupting concepts that were nurtured inside of a society are not easy tasks but concerned citizens can definitely help in creating an alternative reality that allows all to live in peace and seeing the big picture make decisions that not only benefit the science, politics or religion, those decisions must be made to benefit the people and their daily lives while respecting their personal agency as individuals but giving them the chance of choosing. The first amendment to the United States constitution begins, "Congress shall make no law respecting an establishment of religion, or prohibiting the free exercise thereof..." Fast forward almost 250 years and religious freedom is one of the most pressing issues in American culture today. Sometimes, we are given the impression that Christianity, the Church, and religious folks in general have been the enemies of freedom, especially

\footnotetext{
${ }^{18}$ ICELANDIC HUMAN RIGHTS CENTRE. The right to freedom of expression and religion [online]. Available: http://www.humanrights.is/en/human-rights-education-project/human-rights-concepts-ideas-and-fora/substantive-human-rights/the-rightto-freedom-of-expression-and-religion(May 30, 2019)

${ }^{19}$ ZALUAR, A.; GONÇALVES, R. B.Religion and Politics in Brazil: The conservative Evangelical Parliamentary Front [online]. Available: https://ecpr.eu/Filestore/PaperProposal/372ff7fd-0d77-4b7b-98ab-b610a9145039.pdf (June 30, 2019) and SOUZA, E.; TEIXEIRA, H. A. Religion and Politics in Brazil: the role of religion in the 2010 presidential campaign. Available: https://ecpr.eu/filestore/paperproposal/231b54f1-4e70-40fe-a768-db277c3d2978.pdf(June 30, 2019)

20 EPRS | EUROPEAN PARLIAMENTARY RESEARCH SERVICE. Religion and human rights [online]. Available: http://www.europarl.europa.eu/at-your-service/files/be-heard/religious-and-non-confessional-dialogue/events/en-20181204-eprs-briefingreligion-and-human-rights.pdf(May 30, 2019)

${ }^{21}$ OHCHR - UNITED NATIONS HUMAN RIGHTS. International standards on freedom of religion or belief [online]. Available: https://www.ohchr.org/en/issues/freedomreligion/pages/standards.aspx(May 30, 2019)
} 
freedom of conscience. History says otherwise, while most people have the idea that philosophy and the Enlightenment was responsible for creating what we understand as religion freedom, the author Wilken traces the intellectual history of religious freedom to Tertullian (ca. 155-240), a Christian apologist who lived in Roman North Africa and was evidently the first person in Western civilization to use the phrase "freedom of religion" (libertasreligionis). In the ancient world Christian apologists wrote in defense of their right to practice their faith in the cities of the Roman Empire. They argued that religious faith is an inward disposition of the mind and heart and cannot be coerced by external force, laying a foundation on which later generations would build. ${ }^{22}$

The European Court of Human Rights has found that a person cannot be forced to demonstrate views or behaviour associated with a particular religion. ${ }^{23}$ This means, for example, that public authorities should take care when using procedures that involve the swearing of oaths. A requirement to swear on a religious text, such as the Bible, would breach human rights law. An alternative form of affirmation should be available that isn't connected with religion.

While this important subject is debated throughout history both in America and in Europe, a country has seen to bring good precedents to religious freedom: Brazil. While facing many issues with poverty and corruption in the government the country seemed to be rising in the subject.

\section{Religious Freedom in Brazil}

Brazil, the Democratic Republic of the Congo, Japan, Philippines and South Africa have been recognized by the Pew Research Center as countries with the least restrictions and hostilities on religion as of 2014. In Brazil religious groups are free to establish places of worship, train clergy, and proselytize without being required to register. Brazil has lower restrictions, in fact, than the United Kingdom and the United States, where restrictions have been rising. ${ }^{24}$

The country is a party to the International Covenant on Civil and Political Rights ${ }^{25}$.

In 2013 Top regional leaders of 20 faith groups pledged to continue advocating for religious freedom in Brazil during a weekend festival sponsored by the now 120-year-old International Religious Liberty Association. A celebration of freedom of conscience, which highlighted the largely peaceful coexistence of faith groups in Brazil, the event drew nearly 30,000 attendees to the second World Festival of Religious Freedom on Saturday, May 25, in Anhangabaú Valley, an open plaza area in central São Paulo. At the event Brian Grim, senior researcher at the Pew Research Center's Forum on Religion and Public Life, offered an overview of freedom of conscience. He said 40 percent of the world's countries have major restrictions on religious freedom rights. Additionally, one-third of countries have rules that force people to profess some sort of religion, prohibiting atheism. In 31 percent of countries, Grim said, religious intolerance can often result in arrests.

The federal constitution states that freedom of conscience and belief is inviolable, and that free exercise of religious beliefs is guaranteed. In addition, the constitution prohibits federal, state, and local governments from either supporting or hindering any specific religion.

Since the first Constitution of 1824, enacted following the Portuguese Crown tradition, it's clear that the Roman Catholic Church is influential and it's yet the main religion in the nation. The official numbers in the census from 1960 to 2000 have shown that in 1960 there were 93,1\% declared Roman Catholics, 4,0\% Evangelical and 1,4\% Spiritualists. In 2000, among those who declared a religion, the numbers were different: 73,6 \% were Roman Catholics, $15,4 \%$ were Evangelical and 1,6\% were Spiritualists.

According to the 2010 census, an estimated 64.6 percent of the population is Roman Catholic and 22 percent is Protestant. Approximately 60 percent of Protestants belong to Pentecostal churches, 18 percent belong to "mainstream" Protestant churches, and 22 percent belong to other Protestant groups.

Other Christian groups constituting less than 1 percent of the population include Jehovah's Witnesses and The Church of Jesus Christ of Latter-day Saints. Atheists, agnostics, those who claim no religion, and those whose religion is unknown make up roughly 8 percent of the population.

\footnotetext{
${ }^{22}$ Liberty in the Things of God: The Christian Origins of Religious Freedom [online]. Available: https://www.amazon.com/Liberty-ThingsGod-Christian-Religious/dp/0300226632?tag=firstthings20-20(June 4, 2019)

${ }^{23}$ EQUALITY AND HUMAN RIGHT COMISSION OF SCOTLAND AND WALES. Article 9: freedom of thought, belief and religion. Available: https://www.equalityhumanrights.com/en/human-rights-act/article-9-freedom-thought-belief-and-religion(June 3, 2019)

${ }^{24}$ GRIM, B. (2019).Brazil: A Lesson in the Peaceful Navigation of Religious Change [online]. Available:

https://www.religiousfreedominstitute.org/cornerstone/2016/7/14/brazil-a-lesson-in-the-peaceful-navigation-of-religious-change(June 3, 2019)

${ }^{25}$ UNITED NATIONS TREATY COLLECTION. International covenant on civil and political rights [online].Available: https://treaties.un.org/pages/viewdetails.aspx?chapter=4\&clang=_en\&mtdsg_no=iv-4\&src=ind(June 3, 2019) 136
} 
Other groups, each constituting less than 1 percent of the population, include Buddhists, Jews, Muslims, Hindus, and African and syncretic religious groups such as Candomble and Umbanda. There are a small number of adherents of indigenous religious beliefs.

Assessments of the number of Muslims vary. According to the 2010 census, there are approximately 35,200 Muslims, while the Federation of Muslim Associations of Brazil states the number at approximately 1.5 million. Other observers estimate the number of Muslims to be between 400,000 and 500,000. There are significant numbers of Muslims in Sao Paulo, Rio de Janeiro, Curitiba, and Foz do Iguazu, as well as in smaller cities in the states of Parana and Rio Grande do Sul.

According to the Jewish Confederation of Brazil, there are approximately 125,000 Jews, 65,000 of whom reside in Sao Paulo State and 25,000 in Rio de Janeiro State. Many other cities have smaller Jewish communities.

The growing religious pluralism in Brazil has sparked strategies and paths in order to transform and consolidate the relationship of religious groups with the public sphere. Driven by their growing religious and demographic power, large Pentecostal and Neo-Pentecostal churches, for example, began to use mass media to implement policy in recent decades. It must be recognized that a religious market, as in the case of Brazil, has impacted the escalation of religious disputes that oppose Catholic and Evangelical denominations with influence in the public sphere, especially in the political arena and in the electronic media.

\section{Religious Intolerance in Brazil}

All this good news don't clearly show that Brazil was not always known for religious tolerance. Brazil has a rich and complex history of diversity and pluralism, with periods and episodes of significant religious tolerance as well as periods and episodes of significant religious intolerance. In the year 1500, when Pedro Álvares Cabral discovered the Brazilian mainland, approximately 100 million indigenous people occupied the American continent, with approximately 5 million natives in Brazil $^{26}$. With the arrival of the Portuguese came Jesuit missionaries from the Catholic Church. Because the natives followed "religious traditions and rituals that explored the forces of nature and honored the spirits of ancestors, [they] presented a cosmological vision that was considered inferior and profane to Europeans, a vision that was consequently intolerable." In fact, like any other non-Catholic religion, the native's religion was demonized by the Portuguese. They made concerted efforts to convert the natives to Catholicism, and over time the majority of native religions disappeared from $\mathrm{Brazil}^{27}$.

The history of settlement in colonial Brazil is confused with the very history of the implementation of Catholicism in the country through the colonizer, Portugal (ANGELIN, 2011 ${ }^{28}$ ), and this has been the difficulty of inserting other creeds in Catholic Brazil throughout the centuries of occupation. During most of the colonial period, the Tribunal of the Holy Office of the Inquisition, established in Portugal in 1536, was active in Brazil.

For instance, the persecution of Brazilian Jews in the 1600s sent the first group of Jews to New York in $1654 .{ }^{29}$ But writing in 1923, University of Texas legal expert Herman G. James noted that "It is safe to say that there is no other country in the world where the Roman Catholic faith is the traditional and prevailing faith of the inhabitants, where there is a more complete separation of Church and State, or where there is greater freedom of conscience and worship." The stance of the majority faith, Catholicism, has contributed towards religious freedom in Brazil.

In 2017 many incidents were registered. In July the press reported that members of an alleged street vendor mafia in Rio de Janeiro attacked a Syrian refugee in a religiously motivated physical assault. In August and September unknown perpetrators committed acts of arson, vandalism, and destruction of sacred objects against seven terreiros in Nova Iguacu on the outskirts of Rio de Janeiro. Eight similar incidents occurred in Sao Paulo in September. At the end of the year, the perpetrators of the violence remained unidentified and at large.

\footnotetext{
${ }^{26}$ THE NEW YORK TIMES.A brief history of Brazil[online]. Available:

https://archive.nytimes.com/www.nytimes.com/fodors/top/features/travel/destinations/centralandsouthamerica/brazil/riodejaneiro/fdrs_feat 129_9.html?n(June 3, 2019)

${ }^{27}$ SURVIVAL INTERNATIONAL. Brazilian indians [online]. Available: https://www.survivalinternational.org/tribes/brazilian(Jane 3, 2019)

28 ANGELIN, P. E. (2011). As religiões afro-brasileiras no mercado religioso e os ataques das igrejas neopentecostais. Tempo e Argumento, 3 (2) 182-191. Available: http://dx.doi.org/10.5965/2175180303022011182(June 1, 2019)

${ }^{29}$ DEMOGRAFIA UNICAMP: BLOG DOS ESTUDANTES. Brazil has lowest government restrictions on religion among 25 most populous nations, as country undergoes major religious shifts. Available: https://demografiaunicamp.wordpress.com/2013/07/22/brazilhas-lowest-government-restrictions-on-religion-among-25-most-populous-nations-as-country-undergoes-major-religious-shifts.(May 29, 2019)
} 
According to the Ministry of Human Rights' Secretariat of Human Rights (SDH), its hotline received 169 complaints related to cases of religious intolerance between January and June, compared with 377 complaints in the first semester of 2016 and 382 in the second semester of 2016.

Following the attacks on terreiros in Nova Iguazu, in November 2017 the Rio de Janeiro state government established the Joint Commission of the Baixada Fluminense against Religious Intolerance. The commission composed of religious leaders in the Baixada Fluminense on the outskirts of the city of Rio de Janeiro, representatives of the Rio de Janeiro state government, members of the Rio de Janeiro state Public Defender's Office, and civil police officers.

On 409 articles published on religious violence and intolerance from 2011 to 2015 in Brazil, 53 percent involved victims who practiced African-originated religions.

In September 2017 the Brazilian Bar Association created a religious freedom commission. The commission's stated purpose was to allow lawyers and others to discuss legal matters related to religious freedom.

The high level of religious freedom in Brazil is notable as the country arguably undergoes one of the most dynamic religious shifts in the world today, with no religious or sectarian conflict. The Brazilian Constitution embraces freedom of religion as a fundamental right. Brazil's constitution establishes the "promot[ion] of the well-being of all, without prejudice as to origin, race, sex, color, age, and any other forms of discrimination" as one of the "fundamental objectives of the Federative Republic of Brazil."

Article 5, which establishes basic and fundamental human rights, declares in part:

All persons are equal before the law, without any distinction whatsoever, Brazilians and foreigners residing in the country being ensured of inviolability of the right to life, to liberty, to equality, to security and to property, on the following terms: ....

VI. freedom of conscience and belief is inviolable, the free exercise of religious sects being ensured and, under the terms of the law, the protection of places of worship and their rites being guaranteed;

VII. under the terms of the law, the rendering of religious assistance in civil and military establishments of collective confinement is ensured; VIII. no one shall be deprived of any rights by reason of religious belief or philosophical or political conviction, unless he invokes it to exempt himself from a legal obligation required of all and refuses to perform an alternative obligation established by law ...

It is true that religious conflicts are rare in Brazil and that today every group enjoys religious freedom, even to not believe or worship God. As has been shown, the Brazilian government places virtually no restrictions on religious expression in private or in public. Tolerance for the difference and freedom of speech are the key.

Brazilians at the grassroots level plan to promote religious freedom worldwide through a series of initiatives, including hosting the first biannual Business, Faith and Freedom Global Awards ${ }^{30}$ that recognize the best advances and innovations by businesses in improving respect for religious freedom, interfaith understanding, and peace.

While this is a current and happy perspective Brazil does face issues with religious intolerance as seen above. The growth of neo-Pentecostal churches seems to be a problem because of their belief which demonise the Afro-Brazilian cults, it is said that the violence and intolerance is bigger within these two groups. The work: "Religious Intolerance: The impact of the neo pentecostalism in the Afro-Brazilian Field" (Edusp) is a document that gathers essays that approach both the history of such violence directed at religious groups as it reflects on its causes. The project organizer Vagner Silva: "I would say that there is more attack from the Neo-Pentecostal evangelical churches in relation to the Afro group, and the Afro group has only begun to react. ${ }^{31}$ " These attacks reach the maximum limits of the public sphere when evangelical politicians and their allies try to create laws to curb the expression of such religiosities, such as the law against animal sacrifice, laws against despatches in public areas.

Nowadays, people tend to minimize these religious attacks because they are occurring "downstairs", among the disadvantaged classes. Who is attacking whom? It is the "poor" neo pentecostal" citizen attacking the "poor macumbeiro" (follower of macumba, another Afro-Brazilian worship), as they call it. So, this is not affecting the elites. This is a "war", as I call, but not these elites' particular war, and even so has many implication.

\footnotetext{
${ }^{30}$ RELIGIOUS FREEDOM AND BUSINESS. Meet the finalists: 2018 global business \& interfaith peace awards. Available: https://religiousfreedomandbusiness.org/2/post/2017/12/meet-the-finalists-2018-global-business-interfaith-peace-awards.html (June 4, 2019)

${ }^{31}$ LEVY, Helton (2018). The long history of religious intolerance in Brazil [online]. Available:https://medium.com/@ heltonlevy/the-longhistory-of-religious-intolerance-in-brazil-a08533e28060 (June 5, 2019)

138
} 


\section{Means of Solving Conflicts of Religious Intolerance}

An extensive empirical research in the state Rio de Janeiro made by Ana Paula Mendes Miranda, Roberta mellocorrea, Vinicius Cruz Pinto of the Universidade Federal Fluminense published in the Magazine "CONFLUÊNCIAS REVISTA INTERDISCIPLINAR DE SOCIOLOGIA E DIREITO" reported the following: "It was observed that the judges, prosecutors and conciliators interviewed do not observe the cases that are considered habitual deviations from conduct, but as acts generated by "lack of education" and that, therefore, they are not related by them to [the] other crimes. Thus, since cases should not be administered by the Judiciary, this would have to occur between the parties, that is, in the private sphere, which represents an informal way of restricting access to justice. It was also possible to perceive a discredit in the conciliation and the criminal transaction as effective mechanisms for the resolution of the conflict, because it is very difficult to reach an agreement when "futilidades" are discussed. (emphasis mine) The criminal transaction, then, would also have no effect, for not "solve" the issue. Some challenges present themselves. In general, the conciliators sought an "extinction" of that conflict from their denial. We can therefore interpret that for the conciliators most of the events had an illegitimate motivation, which would invalidate the litigation to Justice.",32

In an article published on the CONIC (National Council of Christian Churches of Brazil) website dated of April 22, 2019, it was reported that in the last four years, the number of cases of intolerance in Belém, according to data from the Crime Prevention Police and Homophobic (DCCDH), increased by $900 \%{ }^{33}$. In 2015, a police inquiry into religious intolerance was recorded. In 2016 and 2017, there were four cases each year. As early as 2018, the number of procedures rose to nine. In the first months of 2019, three investigations have already been made.

Time will tell whether Brazil becomes a major global force for religious freedom. Brazil's government is extraordinarily favorable to religious liberty and committed to protecting free exercise of religion both in private and in public. But, as shown clearly in the data, Brazil certainly has a track record of peacefully navigating religious change worth noticing.

\section{For More Information}

About the special court cases in religious intolerancein Brazil:

- http://www.confluencias.uff.br/index.php/confluencias/article/view/466

- $\quad$ https://www.anpocs.com/index.php/papers-36-encontro/gt-2/gt17-2/8042-o-judiciario-e-os-casos-envolvendoconflitos-religiosos/file

- https://siaiap32.univali.br/seer/index.php/nej/article/view/9690

- $\quad$ https://portalrevistas.ucb.br/index.php/rvmd/article/view/7378/4784

- https://www.mdh.gov.br/navegue-por-temas/diversidade-religiosa/publicacoes1/RelatoriosobreIntoleranciaeViolenciaReligiosanoBrasilExpediente2.pdf

- http://www.29rba.abant.org.br/resources/anais/1/1405533580 ARQUIVO RANGEL VICTOR-29RBA2014final.pdf

\section{References}

ABC - AUSTRALIAN BROADCASTING CORPORATION. Human rights and the limits of religious freedom[online]. Available:https://www.abc.net.au/religion/human-rights-and-the-limits-of-religious-freedom/10286070(May 30, 2019)

ACADEMIC IMPACT. \#sdgsinacademia: goal 16 [online]. Available: https://academicimpact.un.org/content/sdgsinacademia-goal16(June 3, 2019)

AISBERG - UNIVERSITY OF BERGAMO INSTITUTIONAL REPOSITORY. Rights of religious minorities and the principle of freedom of religion and belief: a human rights assessment and the case study of the Islamic Republic of Iran [online]. Available: https://aisberg.unibg.it/retrieve/handle/10446/28976/12214/tesi\%20completa\%20.pdf(June 3, 2019)

ANGELIN, P. E. (2011). As religiões afro-brasileiras no mercado religioso e os ataques das igrejas neopentecostais. Tempo e Argumento, 3 (2) 182-191. Available: http://dx.doi.org/10.5965/2175180303022011182(June 1, 2019)

ASCO POST. Relevance of the hippocratic oath in the 21st century [online]. Available:https://www.ascopost.com/issues/october-152014/relevance-of-the-hippocratic-oath-in-the-21st-century.aspx (June 4, 2019)

\footnotetext{
${ }^{32}$ Miranda, A. P. M.;Correa,R.M.;Pinto, V. C. (2016).Conciliação no papel: o tratamento dado aos casos de intolerância religiosa em Juizados Especiais Criminais no Rio de Janeiro.Confluências, 18(2), 21-43.Available:https://doi.org/10.22409/conflu18i2.p466(June 5, 2019)

${ }^{33}$ CONIC - CONSELHO NACIONAL DE IGREJAS CRISTÃS. Crimes de intolerância religiosa crescem 900\% em Belém. Available: http://www.conic.org.br/portal/noticias/3064-crimes-de-intolerancia-religiosa-crescem-900-em-belem (June 5, 2019)
} 
Audebert, Cedric. (2017). The recent geodynamics of Haitian migration in the Americas: refugees or economic migrants?.Revista Brasileira de Estudos de População, 34(1), 55-71. https://dx.doi.org/10.20947/s0102-3098a0007(May 30, 2019)

CONIC - CONSELHO NACIONAL DE IGREJAS CRISTÃS. Crimes de intolerância religiosa crescem $900 \%$ em Belém. Available:http://www.conic.org.br/portal/noticias/3064-crimes-de-intolerancia-religiosa-crescem-900-em-belem (June 5, 2019)

DEMOGRAFIA UNICAMP: BLOG DOS ESTUDANTES. Brazil has lowest government restrictions on religion among 25 most populous nations, as country undergoes major religious shifts. Available:https://demografiaunicamp.wordpress.com/2013/07/22/brazilhas-lowest-government-restrictions-on-religion-among-25-most-populous-nations-as-country-undergoes-major-religious-shifts. (May 29, 2019)

EPRS | EUROPEAN PARLIAMENTARY RESEARCH SERVICE. Religion and human rights [online]. Available: http://www.europarl.europa.eu/at-your-service/files/be-heard/religious-and-non-confessional-dialogue/events/en-20181204-eprsbriefing-religion-and-human-rights.pdf(May 30, 2019)

EQUALITY AND HUMAN RIGHT COMISSION OF SCOTLAND AND WALES. Article 9: freedom of thought, belief and religion. Available: https://www.equalityhumanrights.com/en/human-rights-act/article-9-freedom-thought-belief-and-religion(June 3, 2019)

GOVERNMENT OF CANADA. Freedom of religion or belief [online]. Available: https://international.gc.ca/world-monde/issues_development-enjeux_developpement/human_rightsdroits_homme/freedom_religion-liberte_religion.aspx?lang=eng(June 4, 2019)

GOVERNMENT OFFICES OF SWEDEN. Religious freedom is a fundamental human right [online]. Available: https://www.government.se/opinion-pieces/2018/07/religious-freedom-is-a-fundamental-human-right(August 30, 2019)

GRIM, B. (2019). Brazil: A Lesson in the Peaceful Navigation of Religious Change [online]. Available:

https://www.religiousfreedominstitute.org/cornerstone/2016/7/14/brazil-a-lesson-in-the-peaceful-navigation-of-religious-change(June 2019)

HARRY S. TRUMAN PRESIDENTIAL LIBRARY \& MUSEUM. To secure these rights [online]. Available: https://www.trumanlibrary.org/civilrights/srights4.htm (June 4, 2019)

ICELANDIC HUMAN RIGHTS CENTRE. The right to freedom of expression and religion [online]. Available: http://www.humanrights.is/en/human-rights-education-project/human-rights-concepts-ideas-and-fora/substantive-humanrights/the-right-to-freedom-of-expression-and-religion(May 30, 2019)

JIPPING, Thomas. Diluting the substance of religious freedom [online]. Available: https://www.heritage.org/religiousliberty/commentary/diluting-the-substance-religious-freedom (June 4, 2019)

LEVY, Helton (2018). The long history of religious intolerance in Brazil [online]. Available:https://medium.com/@heltonlevy/the-longhistory-of-religious-intolerance-in-brazil-a08533e28060 (June 5, 2019)

Liberty in the Things of God: The Christian Origins of Religious Freedom [online]. Available:https://www.amazon.com/Liberty-ThingsGod-Christian-Religious/dp/0300226632?tag=firstthings20-20(June 4, 2019)

Miranda, A. P. M.; Correa,R.M.;Pinto, V. C. (2016).Conciliação no papel: o tratamento dado aos casos de intolerância religiosa em Juizados Especiais Criminais no Rio de Janeiro.Confluências, 18(2), 21-43.Available: https://doi.org/10.22409/conflu18i2.p466(June 5, 2019)

OHCHR - UNITED NATIONS HUMAN RIGHTS. International standards on freedom of religion or belief [online]. Available: https://www.ohchr.org/en/issues/freedomreligion/pages/standards.aspx(May 30, 2019)

OHCHR - UNITED NATIONS HUMAN RIGHTS. Report of the united nations special rapporteur on freedom of religion or belief to the general assembly [online]. Available: https://www.ohchr.org/en/issues/freedomreligion/pages/reportsrtothegeneralassembly.aspx(May 30, 2019)

RELIGIOUS FREEDOM \& BUSINESS FOUNDATION. Religious freedom \& sustainable development [online]. Available: https://religiousfreedomandbusiness.org/religious-freedom-sustainable-development(June 3, 2019)

RELIGIOUS FREEDOM \& BUSINESS FOUNDATION. Religious freedom linked to peace, finds new global study [online]. Available: https://religiousfreedomandbusiness.org/2/post/2014/10/religious-freedom-linked-to-peace-finds-new-global-study.html(June 3, 2019)

RELIGIOUS FREEDOM AND BUSINESS. Meet the finalists: 2018 global business \& interfaith peace awards. Available: https://religiousfreedomandbusiness.org/2/post/2017/12/meet-the-finalists-2018-global-business-interfaith-peace-awards.html (June 4, 2019)

SURVIVAL INTERNATIONAL. Brazilian indians [online]. Available:https://www.survivalinternational.org/tribes/brazilian(Jane 3, 2019)

THE GUARDIAN. 'The strain is too much': venezuelan exodus has Brazil at breaking point [online]. Available: https://www.theguardian.com/global-development/2018/dec/24/venezuelan-exodus-brazil-at-breaking-point(May 30, 2019)

THE NEW YORK TIMES. A brief history of brazil [online]. Available:https://archive.nytimes.com/www.nytimes.com/fodors/top/features/travel/destinations/centralandsouthamerica/brazil/ri odejaneiro/fdrs_feat_129_9.html?n(June 3, 2019)

UN SUSTAINABLE DEVELOPMENT GOALS. Goal 16: promote just, peaceful and inclusive societies [online]. Available: https://www.un.org/sustainabledevelopment/peace-justice(June 3, 2019)

UNITED NATIONS TREATY COLLECTION. International covenant on civil and political rights [online]. Available: https://treaties.un.org/pages/viewdetails.aspx?chapter=4\&clang=_en\&mtdsg_no=iv-4\&src=ind(June 3, 2019)

UNITED NATIONS. Universal declaration of human rights [online]. Available: https://www.un.org/en/universal-declaration-humanrights(June 4, 2019)

VIRGINIA MUSEUM OF HISTORY AND CULTURE. Thomaz Jefferson [online]. Available:https://www.virginiahistory.org/collectionsand-resources/virginia-history-explorer/thomas-jefferson (June 4, 2019)

ZALUAR, A.; GONÇALVES, R. B. Religion and Politics in Brazil: The conservative Evangelical Parliamentary Front [online]. Available: https://ecpr.eu/Filestore/PaperProposal/372ff7fd-0d77-4b7b-98ab-b610a9145039.pdf (June 30, 2019) and SOUZA, E.;

TEIXEIRA, H. A. Religion and Politics in Brazil: the role of religion in the 2010 presidential campaign. Available: https://ecpr.eu/filestore/paperproposal/231b54f1-4e70-40fe-a768-db277c3d2978.pdf(June 30, 2019) 